\title{
Germacrone exerts anti-cancer effects on gastric cancer through induction of cell cycle arrest and promotion of apoptosis
}

\author{
Lei Wu, Lifen Wang, Xiangguo Tian, Junyong Zhang and Hua Feng ${ }^{*}$ (i)
}

\begin{abstract}
Background: Germacrone is one of the natural bioactive compounds found in Rhizoma curcuma essential oils. In this study, the potential anti-cancer effect of germacrone in gastric cancer cell line BGC823 was investigated.

Methods: The cell viability and proliferative activity were assessed, and cell cycle analysis was also performed. Hoechst 33258 and Annexin V/PI double staining was used for detection of cell apoptosis. Protein profiles of cell cycle-related and apoptosis-related proteins were assessed.

Results: MTT assay revealed that germacrone had marked cytotoxicity on BGC823 cells. Germacrone induced cell cycle arrest in the G2/M phase via remarkably decreased expression levels of cyclin B1, cdc 2 and cdc $25 \mathrm{c}$. In addition, the treatment with germacrone induced caspase-3 activity and PARP cleavage. These findings demonstrated the effects of germacrone on inhibiting cell proliferation through induction of G2/M phase cell cycle arrest and promotion of cell apoptosis. It also indicated that germacrone functioned through modulations of cell cycle-associated protein expression and mitochondria-mediated apoptosis.
\end{abstract}

Conclusion: These findings will be valuable as the molecular basis for the germacrone-mediated anti-cancer effect against gastric cancer.

Keywords: Germacrone, Cell cycle arrest, Apoptosis, Gastric cancer, BGC823 cells

\section{Background}

Gastric cancer is a frequently occurring malignant cancer type and a leading cause of cancer death globally, especially in some Asian countries like China and Japan [1, 2]. Gastric cancer usually has delayed symptoms, so patients usually already developed into advanced stages of metastasis when diagnosed [3]. The main clinical treatments for gastric cancer often include surgical operation, radiation therapy and chemotherapy. Although for many cases the treatments are effective, the high morbidity rate and low 5-year survival rate of gastric cancer make it a serious health risk [4]. Therefore, more effective therapeutic approaches are of great importance for the prognosis of gastric cancer patients.

\footnotetext{
* Correspondence: wznjhudp87810822@126.com

Department of Digestive Disease, Shandong Provincial Hospital Affiliated to

Shandong University, No. 324, the Five Weft Seven Road, Ji'nan City,

Shandong Province 250021, People's Republic of China
}

Traditional Chinese herbs serving as successful therapeutic drugs in the treatment of different types of cancers have been proved [5]. Rhizoma curcuma, a traditional Chinese herbal medicine, is commonly prescribed for treating inflammation and cancer therapy [6]. Many essential oils of Rhizoma curcuma are the principal bioactive constituents that have anti-inflammatory and anti-tumor properties [7, 8]. Germacrone is a natural bioactive compound found in Rhizoma curcuma essential oils $[9,10]$. Studies on the biological activities of germacrone have demonstrated that it also possesses significant protective effects including anti-bacterial, antifungal, antifeedant, depressant, choleretic, antitussive and vasodilator activities [11-14]. These findings lead to the hypothesis in this study that germacrone might be involved in anti-tumor effect in human gastric cancer.

Cell cycle arrest is an essential regulatory mechanism in cell proliferation and tumor development. A typical feature of cancer cells is the aperiodicity of cell cycle. DNA

(c) The Author(s). 2020 Open Access This article is distributed under the terms of the Creative Commons Attribution 4.0 International License (http://creativecommons.org/licenses/by/4.0/), which permits unrestricted use, distribution, and reproduction in any medium, provided you give appropriate credit to the original author(s) and the source, provide a link to the Creative Commons license, and indicate if changes were made. The Creative Commons Public Domain Dedication waiver (http://creativecommons.org/publicdomain/zero/1.0/) applies to the data made available in this article, unless otherwise stated. 
damage in the cells can activate the repairing system and many signal transduction pathways, which result in cell cycle arrest and apoptosis [15]. G2/M phase is a major cell cycle checkpoint in cancer treatment because it allows the cells containing damaged DNA to repair the damage at the G2/M checkpoint [16]. Germacrone has been reported to induce G0/G1 or G2/M phase cell cycle arrest in various cancer cell lines [13]. Variations of cell cycle regulation in different types of cancer cells might due to differences associated with cell type [17]. It is well studied that cyclin proteins play important roles in regulating cell cycle process [18]. Cyclin B1, cell division cyclin 2 (cdc2) and cdc 25 are crucial regulators associated with the G2 to $M$ phase transition [19].

Apoptosis is another core regulator of cell proliferation and cell death, which makes it a major factor that is targeted for cancer therapy. In the process of apoptosis, caspases function by executing cell death through different apoptotic stimuli $[20,21]$. The distinct roles of caspase family members in cell apoptosis have been widely reported. Caspases associated with apoptosis have been classified based on their functions into the initiator, inhibitor and inflammatory caspases [22, 23]. The regulation of caspase activation involves in different cellular proteins including $\mathrm{Bcl}-2$ protein family, which is known to be involved in the mitochondrial apoptosis pathway. They are classified into two groups as the pro-apoptotic (Bax, Bak) and anti-apoptotic (Bcl-2, Bcl-xl, Bcl-w, Mcl1) proteins $[24,25]$. Bax/Bcl-xl ratio is demonstrated to be highly associated with the extent of apoptosis [26].

Here, the anti-cancer effect of germacrone and underlying mechanisms of its activity were investigated in human gastric cancer cell line BGC823. Changes of cell cycle arrest and apoptosis after germacrone treatment were assessed, and potential mechanisms were explored. Our findings will have valuable perception on the germacrone-mediated anti-cancer effect against gastric cancer.

\section{Methods}

\section{Cell line and morphological assessment}

Human gastric cancer BGC823 cells (obtained from Cell Research Institute of the Chinese Academy of Science) were cultured in RPMI-1640 medium supplemented with $10 \%$ FBS, $100 \mu \mathrm{g} / \mathrm{mL}$ penicillin and $100 \mu \mathrm{g} / \mathrm{mL}$ streptomycin in a humidified incubator at $37^{\circ} \mathrm{C}$ with $5 \%$ $\mathrm{CO}_{2}$. Germacrone (Chengdu MUST Bio-technology CO., LTD, Chengdu, China) in serial concentrations as dissolved in DMSO $(20,40,60,80 \mu \mathrm{M})$ were added to the culture medium. DMSO $(0 \mu \mathrm{M}$ germacrone $)$ was used as control. After incubation for $6,12,18,24$ and $48 \mathrm{~h}$, cell morphological changes were monitored through an inverted microscope (Zeiss Axio Observer A1).
Cell viability assessment using MTT assay

BGC823 cells were seeded into 96-well plate $\left(5 \times 10^{3}\right)$ and were incubated for $24 \mathrm{~h}$. Germacrone in serial concentrations as dissolved in DMSO $(20,40,60$, and $80 \mu \mathrm{M})$ were added to the cells. DMSO ( $0 \mu \mathrm{M}$ germacrone) was used as control. After 12, 24, 48 and $72 \mathrm{~h}$ of germacrone treatment, $50 \mu \mathrm{g}$ MTT was added and cells were incubated in dark at $37^{\circ} \mathrm{C}$ for $4 \mathrm{~h}$. The MTT-containing medium was discarded and the formazan product was dissolved by adding $100 \mu \mathrm{l}$ of DMSO. The solution was shaking for $10 \mathrm{~min}$ in dark and the absorbance value was measured at the wavelength of $570 \mathrm{~nm}$ with a Multiskan Spectrum Microplate Reader (Thermo, USA).

\section{Cell cycle assessment}

BGC823 cells were synchronized in serum-free medium for $24 \mathrm{~h}$ and then treated with DMSO or in serial concentrations of germacrone $(20,40,60$, and $80 \mu \mathrm{M})$ at $37^{\circ} \mathrm{C}$ for $24 \mathrm{~h}$, followed by washing with phosphate buffered saline (PBS) twice. Cells were trypsinized and collected by centrifugation, followed by fixation in $70 \%$ ethanol at $4{ }^{\circ} \mathrm{C}$ for $24 \mathrm{~h}$. After washing with PBS, cells were stained by propidium iodide (PI) in staining solution supplemented with RNase A for $30 \mathrm{~min}$. Cell cycle was assessed using the FACScan flow cytometer. Data were analyzed with the CellQuest software.

\section{Apoptosis assay by Hoechst 33258 staining}

BGC823 cells that were seeded into 12-well plates were incubated with germacrone in serial concentrations $(20$, $40,60,80 \mu \mathrm{M})$ at $37^{\circ} \mathrm{C}$ for $24 \mathrm{~h}$. After washing twice with PBS, cells were fixed in $3.7 \%$ paraformaldehyde solution for $15 \mathrm{~min}$. The fixing solution was discarded, followed by staining with $5 \mu \mathrm{g} / \mathrm{mL}$ Hoechst 33258 for 10 min. Apoptotic cells were then assessed through a Leica fluorescence microscopy at 1000x magnification.

\section{Apoptosis assay by flow cytometry}

The Fluorescein Isothiocyanate (FITC) Annexin V Apoptosis Detection Kit I (BD Pharmingen, San Diego, CA, USA) was used to detect apoptotic cells following the manufacturer's protocol. In summary, BGC823 cells were treated with germacrone in serial concentrations $(20,40,60$, and $80 \mu \mathrm{M})$ at $37^{\circ} \mathrm{C}$ for $24 \mathrm{~h}$. After washing with PBS, cells were trypsinized and subsequently incubated in FITC-conjugated Annexin-V binding buffer containing PI in dark for $15 \mathrm{~min}$. After incubation, cell apoptosis was assessed using a FACScan flow cytometer.

\section{Caspase- $3,-6,-8$ and -9 activity assay}

The protease activities of caspase-3, $-6,-8$ and -9 in BGC823 cells were assessed using the Caspase Activation Kit (Millipore, Billerica, MA, USA) following the manufacture's protocol. Briefly, BGC823 cells were 
resuspended in cell lysis buffer. After 15 min incubation, the supernatant of cell lysates was collected by centrifugation. Total proteins of cell extract were incubated with the mixture of caspase assay buffer and the corresponding caspase substrate specific for caspase- $3,-6,-8$ and -9 at $37^{\circ} \mathrm{C}$ for $1 \mathrm{~h}$. The enzyme-linked optical density of the solution was measured by the immunosorbent assay at $405 \mathrm{~nm}$ wavelength with a spectrocolorimeter.

\section{Western blot}

Equal amount of each protein sample was transferred to SDS-PAGE (12\%) and then transferred to $0.45 \mathrm{~mm}$ PVDF membranes (Merck, Darmstadt, Germany), followed by blocking with TBST containing 5\% skim milk for $1 \mathrm{~h}$, and subsequent incubation with the corresponding primary antibody (1:1000, Cell Signaling Technology, Danvers, Mass, USA) at $4{ }^{\circ} \mathrm{C}$ for overnight, followed by incubation with HRP-conjugated secondary antibody (1:2000, Santa Cruz Biotechnology, Santa Cruz, CA, USA) for $2 \mathrm{~h}$. Protein signals were detected by the enhanced chemiluminescence (ECL) assay. The Image $J(\mathrm{NIH})$ software was used for quantification of proteins that were normalized relative to $\beta$-actin.

\section{Statistical analysis}

Data values were presented as the mean \pm standard deviation (SD) of three independent experiments. Significant difference for multiple-group comparison was performed by ANOVA analysis. Statistically significant difference was considered when $P$ value $<0.05$.

\section{Results}

Germacrone inhibits cell proliferation and viability of BGC823 cells

The changes caused by germacrone (chemical structure was shown in Fig. 1A) treatment on BGC823 cell morphology was observed under an optical microscopy at $200 x$ magnification. Compared with the control group, in which cells without germacrone treatment exhibited normal morphology with well-shaped and orderly arrangement, the germacrone-treated cells $(24 \mathrm{~h})$ exhibited obvious morphological changes including shrunk, unclear shape, nuclear condensation, fewer number and disorderly arrangement of cells (Fig. 1B). All these morphological changes that are indicative of cell apoptotic death were observed with $12 \mathrm{~h}$ of treatment and became more remarkable as the increasing of germacrone concentration $(20,40,60$ and $80 \mu \mathrm{M})$ and treatment time $(12,24,48$ and $72 \mathrm{~h}$ ) (data not shown). The MTT assay revealed that germacrone treatment significantly inhibited the growth of BGC823 cells and the degree of inhibition depends on both the concentration of germacrone and time of treatment $(P<0.05, P<0.01)$ (Fig. $1 C)$.

\section{Germacrone induced G2/M cell cycle arrest in gastric cancer cells}

The effects of germacrone on cell cycle status of gastric cancer cells were assessed. The cell cycle distribution results showed that exposure of BGC823 cells to germacrone lead to a significant increase of cells at $\mathrm{G} 2 / \mathrm{M}$ phase $(P<0.05, P<0.01)$, while there was a significant decrease at $\mathrm{S}$ phase $(P<0.01)$ (Fig. 2). The percentage of BGC823 cells at the G2/M phase increased from $33.7 \pm 1.22 \%$
A<smiles>CC1=CCC(=C(C)C)CC(=O)C1</smiles>

B

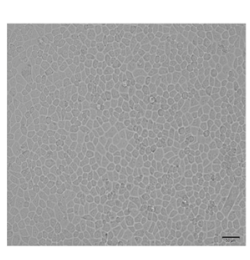

DMSO

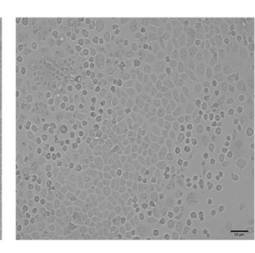

$20 \mu \mathrm{M}$

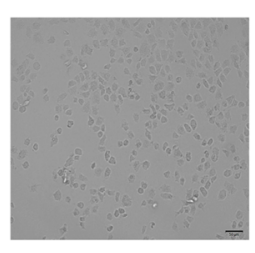

$40 \mu \mathrm{M}$

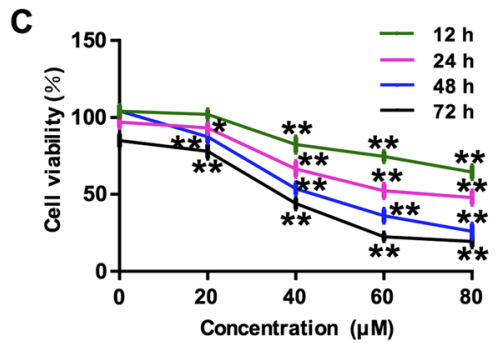

Fig. 1 Effect of germacrone on BGC823 cell proliferation and cell morphological changes. Cells were treated with germacrone at a serial of concentrations $(0,20,40,60$, and $80 \mu \mathrm{M})$ for 12, 24, 48 and $72 \mathrm{~h}$. a The chemical structure of germacrone. b Morphological observations BGC823 cells under optical microscopy at 200x magnification after $24 \mathrm{~h}$ treatment of germacrone in serial concentrations $(0,20,40,60$, and $80 \mu \mathrm{M})$. c MTT assay showing the effect of germacrone on BGC823 cell proliferation cell. "**: $P<0.05$, "***: $P<0.01$ 
(control) to $34.76 \pm 0.75 \%, 35.98 \pm 1.05 \%, 37.97 \pm 1.66 \%$, and $42.66 \pm 2.06 \%$ after treatment with $20,40,60$ and $80 \mu \mathrm{M}$ of germacrone, respectively. And the percentage of BGC823 cells at S phase decreased from $29.4 \pm 0.72 \%$ (control) to $27.81 \pm 0.77 \%, 25.56 \pm 0.66 \%, 22.9 \pm 0.95 \%$, $20.52 \pm 0.63 \%$ after treated with $20,40,60$ and $80 \mu \mathrm{M}$ of germacrone, respectively. Cells at G0/G1 phase were not significantly changed after germacrone treatment $(P>0.05)$.

\section{Germacrone down-regulated the expression of cyclin B1,}

\section{cdc 2 and cdc 25 c}

Protein expression profile was analyzed on three G2/M phase cell cycle-associated proteins including cyclin B1, cdc 2 and cdc $25 \mathrm{c}$ by Western blot. Germacrone treatment induced a decrease of the expression of cyclin B1, cdc 2 , and cdc $25 \mathrm{c}$, and the degree of decrease improved with the increasing of germacrone concentration (Fig. 3A). It showed a markedly decrease when germacrone concentrations were 60 and $80 \mu \mathrm{M}(P<0.05, P<0.01)$ (Fig. 3B$D)$. These results indicated that germacrone-induced cell cycle arrest was associated with the downregulation of cyclin B1, cdc 2, and cdc 25c.

\section{Germacrone induced BGC823 cell apoptosis}

The cell morphological changes observed after germacrone treatment were characteristic of cell apoptosis. To verify that germacrone can induce cell apoptosis,
Hoechst staining and Annexin V-PI double staining were performed in BGC823 cells with $24 \mathrm{~h}$ treatment of germacrone at different concentrations $(20,40,60$ and $80 \mu \mathrm{M})$. As shown in Fig. 4A, compared with the cells without germacrone treatment, germacrone-treated cells had small and bright blue nuclei, which is indicative of cell apoptosis. Similarly, increasing dose of germacrone progressively increased cell apoptosis as indicated by the dose-dependent decrease of proportions of intact cells (Fig. 4B). These evidences proved that germacrone can induce apoptosis in BGC823 cells.

\section{Germacrone altered the expression of apoptosis- regulatory proteins}

To further investigate the underlying mechanisms involved in germacrone-promoted apoptosis, expression levels of apoptosis-associated proteins were evaluated. Two mitochondria apoptosis-associated protein, $\mathrm{Bcl}-\mathrm{xL}$ and $\mathrm{Bax}$, were investigated. Western blot analysis showed that compared with cells without germacrone treatment, expression of pro-apoptotic protein Bax markedly up-regulated with the increase of germacrone concentration with a dosedependent manner (Fig. 5A), whereas expression of antiapoptotic protein $\mathrm{Bcl}-\mathrm{xL}$ markedly down-regulated, with a dose-dependent manner as well. And the $\mathrm{Bax} / \mathrm{Bcl}-\mathrm{xL}$ ratio significantly increased when germacrone concentration is at 40,60 and $80 \mu \mathrm{M}(P<0.05, P<0.01)$ (Fig. 5B). Expressions of other apoptosis-related proteins were also assessed

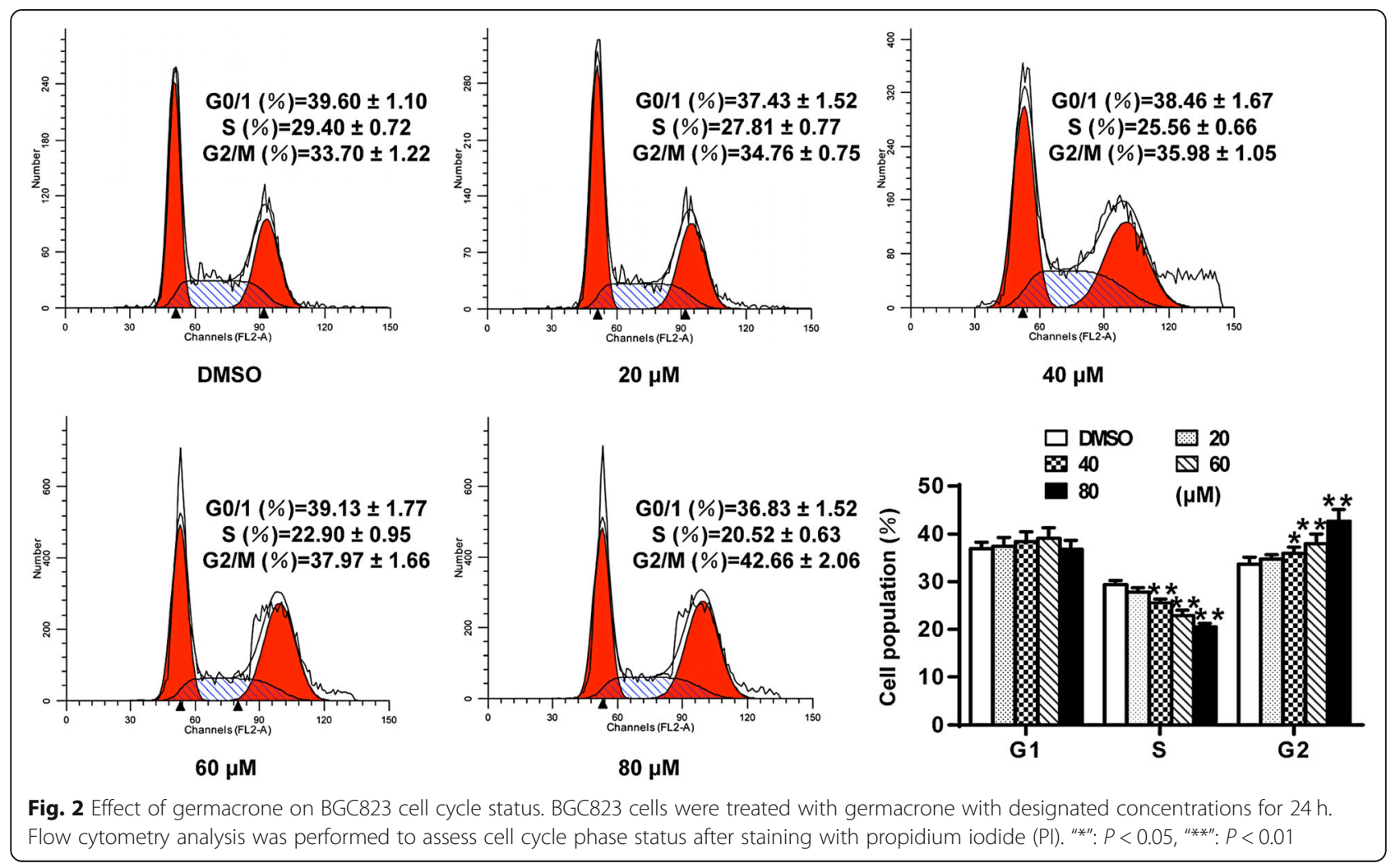




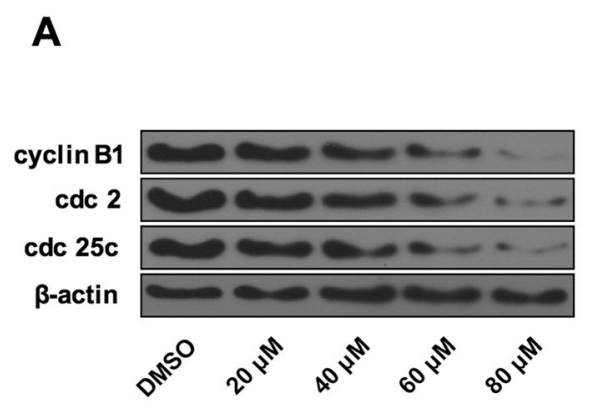

B
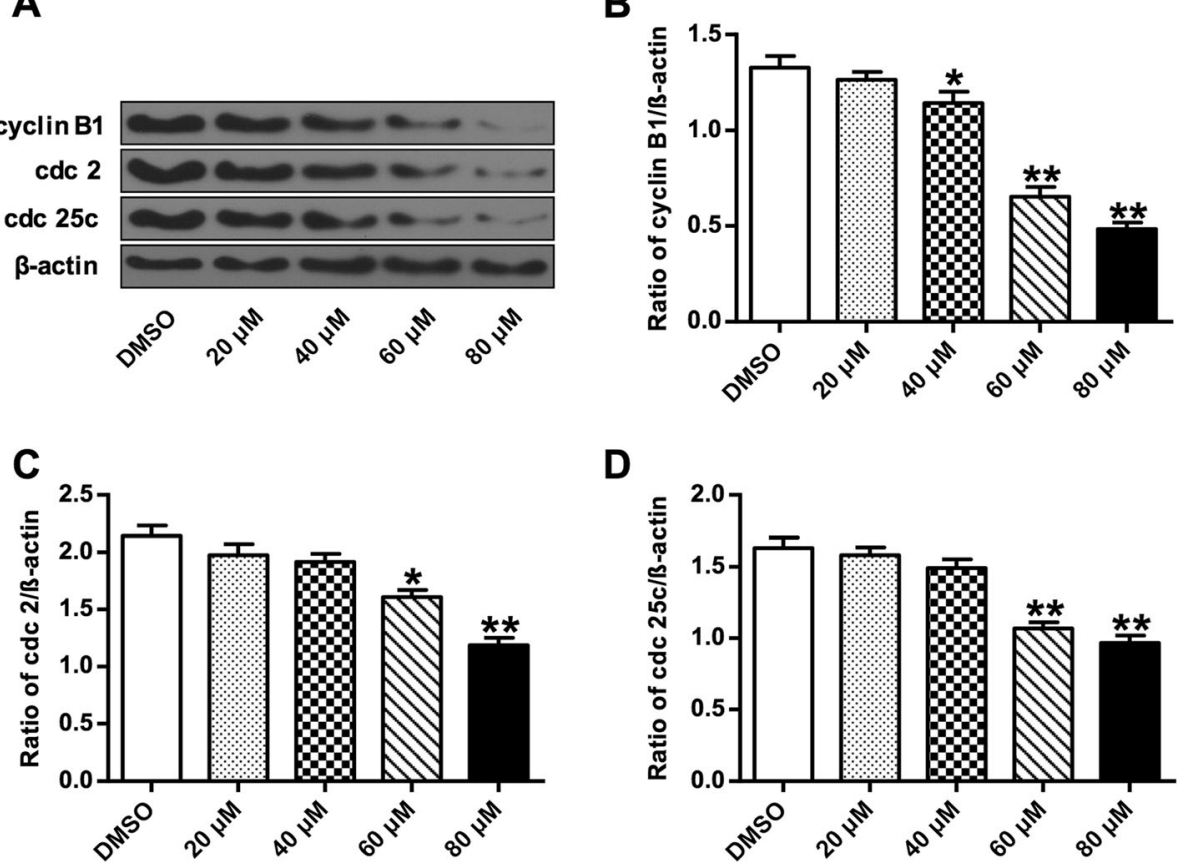

D

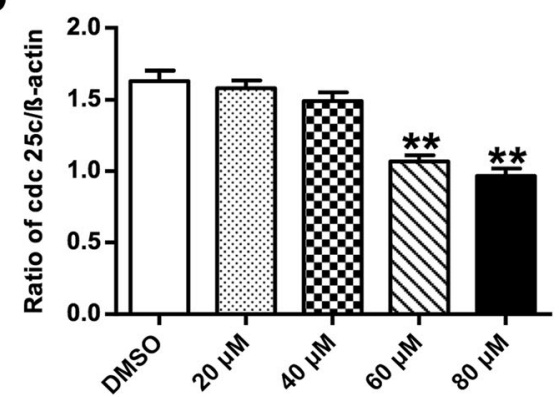

Fig. 3 Western blot analysis of cell cycle-associated proteins. Total proteins were prepared after BGC823 cells were treated with germacrone at different concentreations $(0,20,40,60$, and $80 \mu \mathrm{M})$ and then analyzed by western blotting. a Representative blotting bend intensities used for the quantification of (b) protein cyclin B1, (c) protein cdc 2 and (d) protein cdc 25 c. $\beta$-actin was used as an internal control. "**": $P<0.05$, "***": $P<0.01$

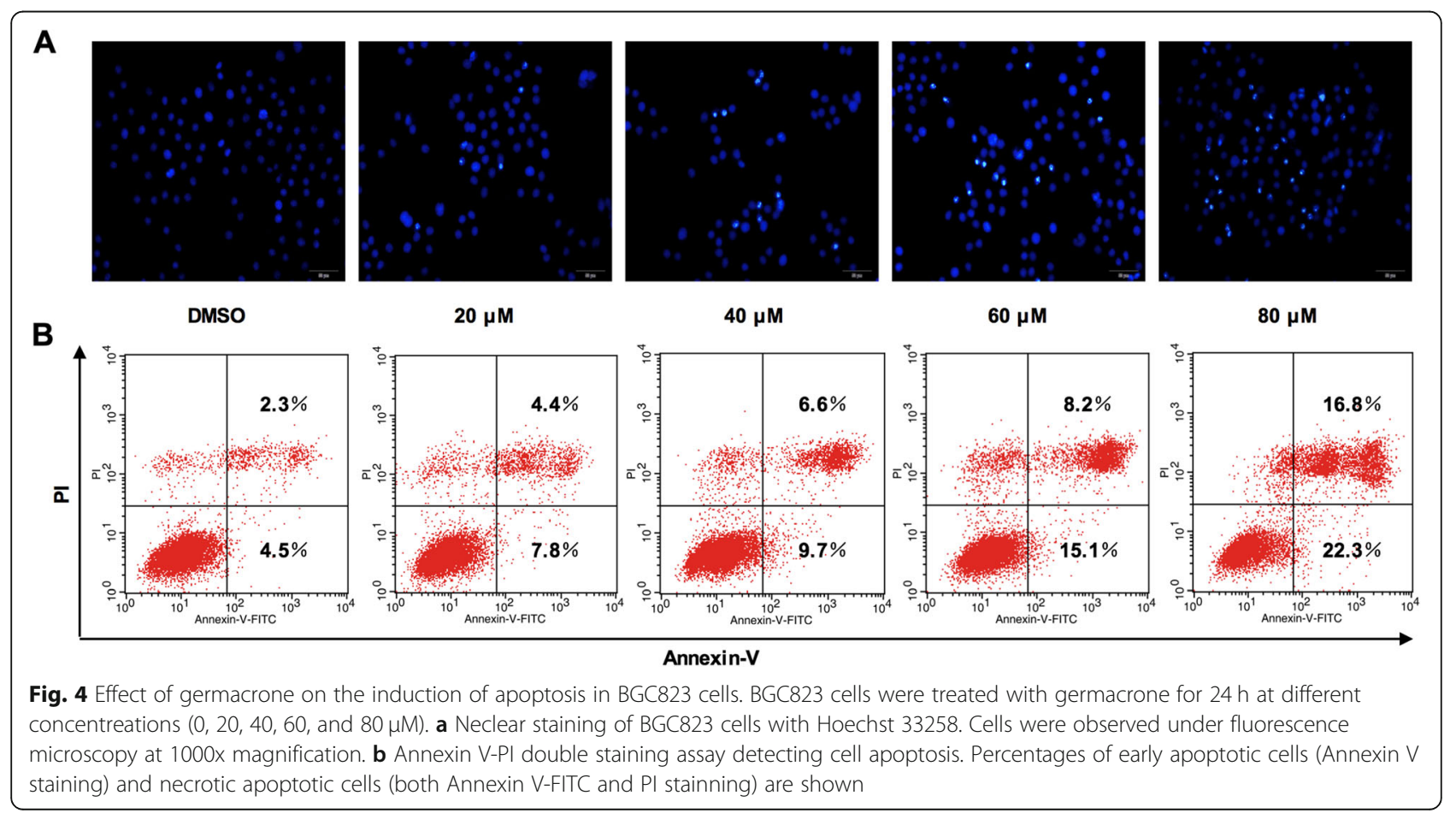



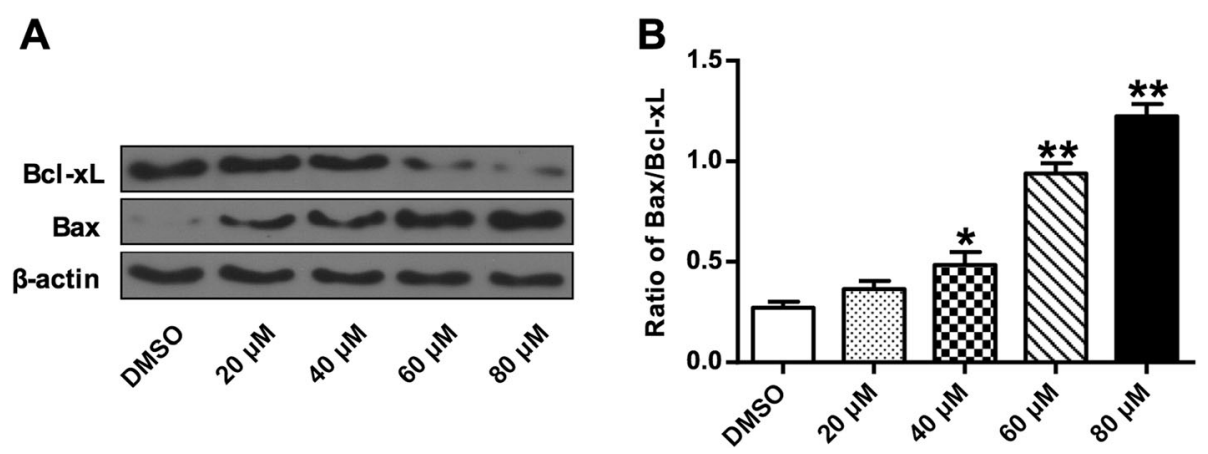

Fig. 5 Effect of germacrone on the expression of mitochondria apoptosis-regulatory proteins Bax and BCl-xL. Total proteins were prepared after BGC823 cells were treated with germacrone at different concentreations $(0,20,40,60$, and $80 \mu \mathrm{M})$ and then analyzed by western blotting. a Representative blotting bend intensities used for the quantification of Bax and BCl-XL. b Quantitative data of the Bax/BCl-XL ratio from protein expression. $\beta$-actin was used as an internal control. "**: $P<0.05$, "**": $P<0.01$

by western blot, including procaspase- $3,-6,-8,-9$, cleaved PARP and cleaved caspase-3, -6, -8, -9 (Fig. 6A). Compared with cells without germacrone treatment, the expression levels of procaspase- $3,-6,-8$, and -9 gradually decreased with the increasing concentrations of germacrone $(P<0.05, P<0.01)$ (Fig. 6B-E). The expression of cleaved PARP and cleaved caspase-3, $-6,-8,-9$ increased dose-dependently with germacrone treatment $(P<0.01)$ (Fig. 6F). And the caspase-3 activities significantly increased after treating with germacrone $(P<0.05, P<0.01)$
(Fig. 6G). These results indicated the effect of germacrone on inducing cell apoptosis by regulating the mitochondria apoptosis pathway and the caspase dependent pathway.

\section{Discussions}

Many traditional plant-derived medicinal herbs have been proved as effective and safe pharmaceutical compounds in cancer therapy, especially in Asian countries. The anti-cancer effect of germacrone, the component isolated from Rhizoma curcuma, was demonstrated in
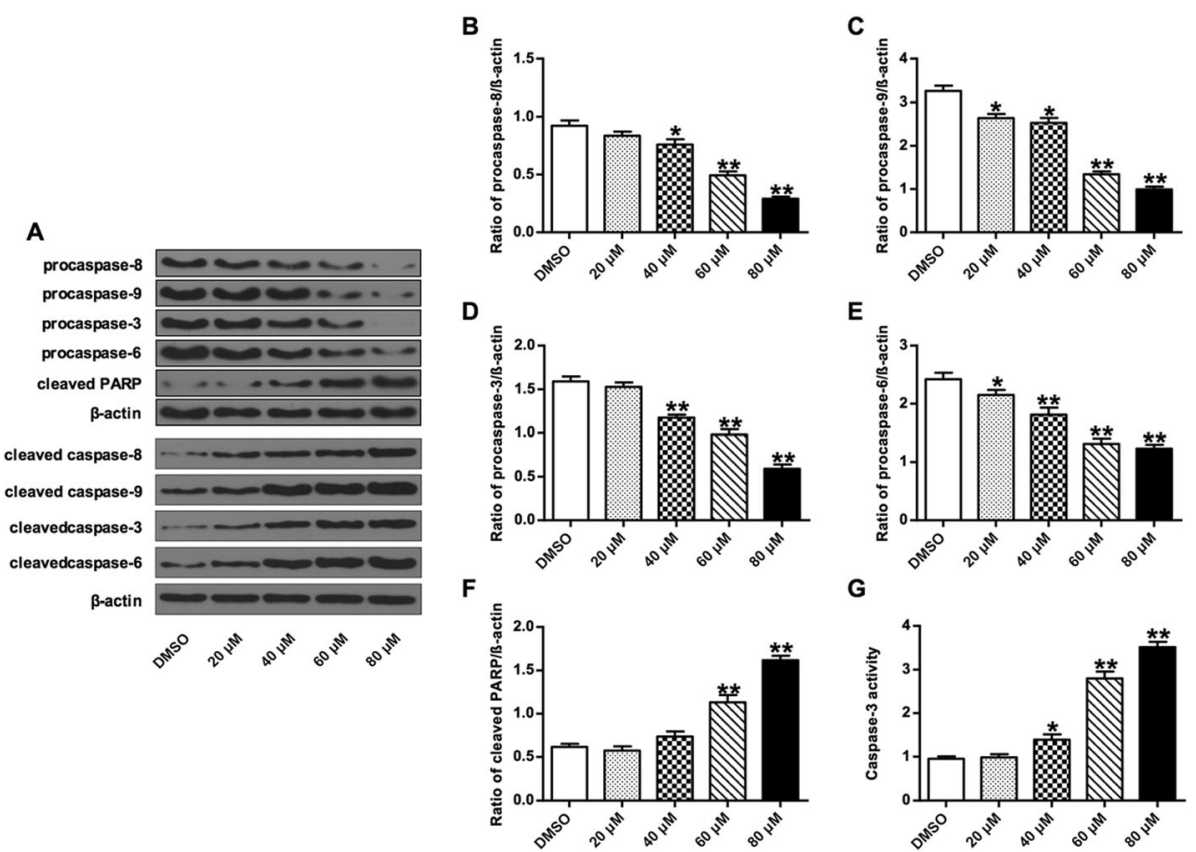

E

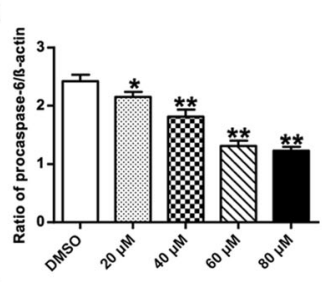

G

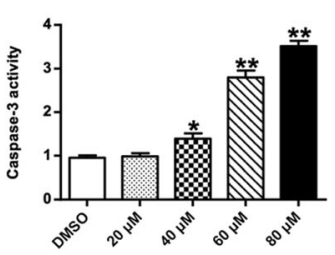

Fig. 6 Effect of germacrone on the expression of apoptosis-associated proteins procaspase-3, $-6,-8,-9$, cleaved caspase-3, $-6,-8,-9$, and cleaved PARP. Total proteins were prepared after BGC823 cells were treated with germacrone at different concentreations $(0,20,40,60$, and $80 \mu \mathrm{M})$ and then analyzed by western blotting. a Representative blotting bend intensities of procaspase-3,-6,-8, -9 , cleaved caspase-3,-6,-8,-9 and cleaved PARP that were used for quantification of protein procaspase-8 $(\mathbf{b})$, protein procaspase-9 (c), protein procaspase-3 (d) protein procaspase-6 (e), and protein cleaved PARP (f) expressions. (g) Caspase-3 activity. $\beta$-actin was used as an internal control. " ${ }^{\prime \prime \prime}: P<0.05$, "***": $P<0.01$ 
different cancer cells, including hepatocellular carcinoma, breast cancer, ovarian cancer, hepatoma and glioma [13, 27-29]. Here, the anti-cancer effect of germacrone was studied in gastric cancer cells. Viability assays revealed that germacrone could inhibit cell proliferation in the dose- and treatment time-dependent manner in BGC823 cells. As the anti-tumor capabilities of Rhizoma curcuma have been identified clinically in China [30], findings in the present study are inspiring for future studies on investigating the bioactivities of other volatile oil components isolated from Rhizoma curcuma, such as $\beta$-elemene, curcumol, curdione, neocurdione, etc.

Reduced cell proliferation resulted from cell cycle arrest is a typical feature in tumor suppression and has been widely demonstrated in different cancer cells. The G2/M checkpoint prevents cell cycle progression by repairing damaged DNA in the cell [16]. The induction of G2/M phase cell cycle arrest in suppressing cancer cell proliferation has been demonstrated in various cancer cells. For example, aloperine induces $\mathrm{G} 2 / \mathrm{M}$ phase cell cycle arrest in human colon cancer cells [31], quercetin induces G2/M phase cell cycle arrest in human cervical cancer cells [32], and tetrahydroingenol diterpenoid induces $\mathrm{G} 2 / \mathrm{M}$ phase cell cycle arrest in melanoma cancer cells [33]. Findings in the present study showed convincingly that germacrone inhibits cell proliferation in BGC823 cells by inducing G2/ $M$ phase arrest in the dose-dependent manner, while with a significant inhibition of the $\mathrm{S}$ phase. Lee et al. reported that similar to germacrone's anti-cancer effect, flavonoids induced G2/M phase cell cycle arrest and cell apoptosis in human gastric cancer AGS cells [34]. In the cell cycle progression, cyclin B1, cdc 2 , and cdc $25 \mathrm{c}$ are very influential proteins in the G2/M phase. Cyclin B1 and cdc 2 form a protein complex and regulate the transition from $\mathrm{G} 2$ to $\mathrm{M}$ phase. And cdc 25 regulates the protein complex formed between cyclin B and cdc 2 [19]. In the present study, germacrone down-regulated the expression of cyclin $\mathrm{B} 1, \mathrm{cdc}$ 2 and cdc $25 \mathrm{c}$ proteins, resulting in the suppression of BGC823 cell growth by inhibiting cell cycle progression in the $\mathrm{G} 2 / \mathrm{M}$ phase. The activity of cyclinB1/cdc2 complex is regulated by many factors in G2/M transition, and downregulation of cyclin B1 by germacrone observed in this study provided insights into the regulation of cell cycle progression. In addition to cyclins, cyclin-dependent kinases (cdks) are also important proteins in the cell cycle progression [18]. CDK2 has been identified as a key regulator of S phase cell cycle progression [35]. The cyclin E and cdk2 can form a protein complex and regulate cell cycle progression in late G1 phase. The cyclin D and cdk4/cdk6 form a complex to mediate cell cycle progression in the mid-G1 phase [36, 37]. The expressions of cdk proteins by the regulation of germacrone in BGC823 cells, which is not investigated in the present study, could be a promising point of view in further studies on the germacrone-regulated cell cycle progression in gastric cancer.

Apoptosis is a critical process in protecting organisms against abnormal growth by excluding cells that have been proliferated improperly. The Bcl- 2 protein family contains key regulators that are involved in mitochondrial pathway-regulated apoptosis. Bcl-2 and Bcl-xL bind to mitochondria outer membrane to block the release of cytochrome $c$ to the cytosol. The pro-apoptotic proteins Bax and Bak are essential for mitochondria outer membrane permeabilization during apoptosis [38, 39]. As expected, our results revealed that germacrone induced apoptosis of BGC823 cells. Germacrone treatment showed significant increase in the expression levels of pro-apoptotic Bax and significant decrease in the expression levels of anti-apoptotic Bcl-xL. Caspases play critical roles in apoptosis as well. The apoptosis resulted from germacrone treatment was matching with the morphological changes in BGC823 cells. Germacrone treatment resulted in down-regulation of procaspase-3, -6 , -8 , and -9 , which in turn induced the activity of cleaved caspase- $3,-6,-8$, and -9 , which are essential caspases in the regulation of apoptosis [40]. The enhanced activity of caspase- 3 also induced the cleavage of poly-ADP-ribose polymerase (PARP), which is a distinguishing feature of caspase-dependent apoptosis [41].

This study emphasized on elucidating the function of germacrone in anti-proliferative and pro-apoptotic of BGC823 cells. However, except for cell proliferation and apoptosis, essential biological features of malignant tumors also include cell metastasis. Cancer metastasis is one of the major reasons causing cancer aggravation and mortality in gastric cancer patients [42, 43]. For instance, studies have demonstrated that matrix metalloproteinases (MMPs) altered their expressions in gastric cancer metastatic tumors, and they could be used as prognostic diagnostic markers in advanced gastric cancer patients as their up-regulation promoted caner metastasis in malignant tumors [44-46]. Therefore, more thorough studies are in need to explore the anti-tumor effects of germacrone, also to further elucidate its mechanisms of regulating gastric cancer. The regulations of all these important regulators by germacrone could be serving as promising therapeutic targets for gastric cancer.

\section{Conclusion}

In conclusion, germacrone inhibits the proliferation of gastric cancer BGC823 cells by inducing the G2/M phase cell cycle arrest and apoptosis through regulation of cell cycle-associated proteins cyclin B1, cdc 2 , and cdc $25 \mathrm{c}$, and apoptosis-associated proteins procaspase- $3,-6$, $-8,-9$, cleaved caspase- $3,-6,-8,-9$ and cleaved PARP. This study provides insights into the application of germacrone in gastric cancer treatment. 


\section{Acknowledgments}

Not applicable.

\section{Ethics approval and consent to participant}

Not applicable.

\section{Authors contributions}

LW, LFW, XGT, JYZ, HF contributed to data analysis, drafting or revising the article, gave final approval of the version to be published, and agree to be accountable for all aspects of the work.

\section{Funding}

This work was supported by the Key Research and Development Project of Shandong Province (Grant NO. 2017GSF18144).

\section{Availability of data and materials}

The analyzed data sets generated during the study are available from the corresponding author on reasonable request.

\section{Consent for publication}

All authors have read and approved the final manuscript.

\section{Competing interests}

The authors declare that they have no competing interests.

\section{Received: 11 May 2019 Accepted: 24 December 2019}

\section{0.}

\section{References}

1. Ferlay J, Soerjomataram I, Dikshit R, Eser S, Mathers C, Rebelo M, et al. Cancer incidence and mortality worldwide: sources, methods and major patterns in GLOBOCAN 2012. Int J cancer Wiley Online Library. 2015;136:E359-86.

2. Siegel RL, Miller KD, Fedewa SA, Ahnen DJ, Meester RGS, Barzi A, et al. Colorectal cancer statistics, 2017. CA Cancer J Clin Wiley Online Library. 2017:67:177-93.

3. De Vries AC, Kuipers EJ. Epidemiology of premalignant gastric lesions: implications for the development of screening and surveillance strategies. Helicobacter Wiley Online Library. 2007;12:22-31.

4. Shitara K, Kadowaki S, Nishina T, Sakai D, Yoshikawa R, Piao Y, et al. Safety, pharmacokinetic, and clinical activity profiles of ramucirumab in combination with three platinum/fluoropyrimidine doublets in Japanese patients with chemotherapy-naive metastatic gastric/gastroesophageal junction cancer. Gastric Cancer Springer. 2018;21:106-13.

5. Liu Y-H, Li M-L, Hsu M-Y, Pang Y-Y, Chen I, Chen C-K, et al. Effects of a Chinese herbal medicine, Guan-Jen-Huang (Aeginetia indica Linn.), on renal cancer cell growth and metastasis. Evidence-Based Complement Altern Med. Hindawi; 2012;2012.

6. Rodrigo G, Almanza GR, Cheng Y, Peng J, Hamann M, Duan R-D, et al. Antiproliferative effects of curcuphenol, a sesquiterpene phenol. Fitoterapia Elsevier. 2010;81:762-6.

7. Makabe H, Maru N, Kuwabara A, Kamo T, Hirota M. Anti-inflammatory sesquiterpenes from Curcuma zedoaria. Nat Prod Res Taylor \& Francis. 2006; 20:680-5.

8. Li Y, Wo JM, Liu Q, Li X, RCG M. Chemoprotective effects of Curcuma aromatica on esophageal carcinogenesis. Ann Surg Oncol Springer. 2009;16:515.

9. Yang FQ, Li SP, Chen Y, Lao SC, Wang YT, Dong TTX, et al. Identification and quantitation of eleven sesquiterpenes in three species of Curcuma rhizomes by pressurized liquid extraction and gas chromatography--mass spectrometry. J Pharm Biomed Anal Elsevier. 2005;39:552-8,

10. Yang FQ, Wang YT, Li SP. Simultaneous determination of 11 characteristic components in three species of Curcuma rhizomes using pressurized liquid extraction and high-performance liquid chromatography. J Chromatogr A Elsevier. 2006;1134:226-31.

11. Xiao $X$, Zhao $Y$, Yuan $H$, Xia W, Zhao J, Wang X. Study on the effect of Rhizoma Curcuma longa on gastrin receptor. Zhong yao cai= Zhongyaocai= J Chinese Med Mater. 2002:25:184-5.

12. Cho W, Nam J-W, Kang H-J, Windono T, Seo E-K, Lee K-T. Zedoarondiol isolated from the rhizoma of Curcuma heyneana is involved in the inhibition of iNOS, COX-2 and pro-inflammatory cytokines via the downregulation of NF-\$K\$B pathway in LPS-stimulated murine macrophages. Int Immunopharmacol Elsevier. 2009;9:1049-57.
13. Liu Y, Wang W, Fang B, Ma F, Zheng Q, Deng P, et al. Anti-tumor effect of germacrone on human hepatoma cell lines through inducing G2/M cell cycle arrest and promoting apoptosis. Eur J Pharmacol. Elsevier. 2013;698:95-102.

14. Ye L, Wu J, Chen W, Feng Y, Shen Z. Novel anti-cancer agents based on germacrone: design, synthesis, biological activity, docking studies and MD simulations. RSC Adv Royal Society of Chemistry. 2017;7:3760-7.

15. Jin C-Y, Choi YH, Moon D-O, Park C, Park Y-M, Jeong S-C, et al. Induction of G2/ $\mathrm{M}$ arrest and apoptosis in human gastric epithelial AGS cells by aqueous extract of Agaricus blazei. Oncol Rep Spandidos Publications. 2006;16:1349-55.

16. Wang Y, Ji P, Liu J, Broaddus RR, Xue F, Zhang W. Centrosome-associated regulators of the $\mathrm{G} 2 / \mathrm{M}$ checkpoint as targets for cancer therapy. Mol Cancer. BioMed Central; 2009:8:8.

17. Bernhaus A, Fritzer-Szekeres M, Grusch M, Saiko P, Krupitza G, Venkateswarlu $S$, et al. Digalloylresveratrol, a new phenolic acid derivative induces apoptosis and cell cycle arrest in human HT-29 colon cancer cells. Cancer Lett. Elsevier. 2009;274:299-304.

18. Shin SY, Yong Y, Kim CG, Lee YH, Lim Y. Deoxypodophyllotoxin induces G2/M cell cycle arrest and apoptosis in HeLa cells. Cancer Lett Elsevier. 2010;287:231-9.

19. Lee SM, Kwon Jl, Choi YH, Eom HS, Chi GY. Induction of G2/M arrest and apoptosis by water extract of Strychni semen in human gastric carcinoma AGS cells. Phyther res an Int J devoted to Pharmacol Toxicol Eval Nat prod Deriv. Wiley Online Library. 2008;22:752-8.

20. Earnshaw WC, Martins LM, Kaufmann SH. Mammalian caspases: structure, activation, substrates, and functions during apoptosis. Annu rev Biochem. Annual reviews 4139 El Camino way, PO Box 10139, Palo Alto, CA 943030139. USA. 1999:68:383-424.

21. Stennicke HR, Salvesen GS. Properties of the caspases. Biochim Biophys Acta (BBA)-protein Struct Mol Enzymol. Elsevier. 1998;1387:17-31.

22. Jin Z, El-Deiry WS. Overview of cell death signaling pathways. Cancer Biol Ther Taylor and Francis. 2005:4:147-71.

23. Mcllwain DR, Berger T, Mak TW. Caspase functions in cell death and disease. Cold Spring Harb Perspect Biol. Cold Spring Harbor Lab; 2013;5:a008656.

24. Lindsay J, Degli Esposti M, Gilmore AP. BCl-2 proteins and mitochondria—specificity in membrane targeting for death. Biochim Biophys Acta (BBA)-molecular cell res. Elsevier. 2011;1813:532-9.

25. Reyes-Zurita FJ, Rufino-Palomares EE, Lupiáñez JA, Cascante M. Maslinic acid, a natural triterpene from Olea europaea L., induces apoptosis in HT29 human colon-cancer cells via the mitochondrial apoptotic pathway. Cancer Lett. Elsevier. 2009;273:44-54.

26. Adams JM, Cory S. The Bcl-2 protein family: arbiters of cell survival. Science (80- ). American Association for the Advancement of Science; 1998;281:1322-6.

27. Zhong Z, Chen X, Tan W, Xu Z, Zhou K, Wu T, et al. Germacrone inhibits the proliferation of breast cancer cell lines by inducing cell cycle arrest and promoting apoptosis. Eur J Pharmacol. Elsevier. 2011;667:50-5.

28. Deng C, Ji J, Li N, Yu Y, Duan G, Zhang X. Fast determination of curcumol, curdione and germacrone in three species of Curcuma rhizomes by microwave-assisted extraction followed by headspace solid-phase microextraction and gas chromatography--mass spectrometry. J Chromatogr A. Elsevier. 2006;1117:115-20.

29. Liu B, Gao Y-Q, Wang X-M, Wang Y-C, Fu L-Q. Germacrone inhibits the proliferation of glioma cells by promoting apoptosis and inducing cell cycle arrest. Mol Med Rep Spandidos Publications. 2014;10:1046-50.

30. Wang. A traditional Chinese medicine formulation consisting of Rhizoma Corydalis and Rhizoma Curcumae exerts synergistic anti-tumor activity. Oncol Rep [Internet]. 2009;22. Available from: http://www.spandidospublications.com/or/22/5/1077

31. Zhang $L$, Zheng $Y$, Deng $H$, Liang $L$, Peng J. Aloperine induces G2/M phase cell cycle arrest and apoptosis in HCT116 human colon cancer cells. Int J Mol Med Spandidos Publications. 2014;33:1613-20.

32. Priyadarsini RV, Murugan RS, Maitreyi S, Ramalingam K, Karunagaran D, Nagini $\mathrm{S}$. The flavonoid quercetin induces cell cycle arrest and mitochondriamediated apoptosis in human cervical cancer (HeLa) cells through p53 induction and NF-\$k\$B inhibition. Eur J Pharmacol Elsevier. 2010;649:84-91.

33. Fallahian $F$, Ghanadian M, Aghaei M, Zarei SM. Induction of G2/M phase arrest and apoptosis by a new tetrahydroingenol diterpenoid from Euphorbia erythradenia Bioss. in melanoma cancer cells. Biomed Pharmacother. Elsevier; 2017;86:334-342.

34. Lee D-H, Park K-I, Park H-S, Kang S-R, Nagappan A, Kim J-A, et al. Flavonoids isolated from Korea Citrus aurantium L. induce G2/M phase arrest and apoptosis in human gastric cancer AGS cells. Evidence-Based Complement Altern Med. Hindawi; 2012;2012. 
35. Chen X-Z, Cao Z-Y, Chen T-S, Zhang Y-Q, Liu Z-Z, Su Y-T, et al. Water extract of Hedyotis Diffusa Willd suppresses proliferation of human HepG2 cells and potentiates the anticancer efficacy of low-dose 5 -fluorouracil by inhibiting the CDK2-E2F1 pathway. Oncol Rep. Spandidos Publications. 2012;28:742-8.

36. Guadagno TM, Ohtsubo M, Roberts JM, Assoian RK. A link between cyclin A expression and adhesion-dependent cell cycle progression. Science (80- ). American Association for the Advancement of Science; 1993;262:1572-5.

37. King RW, Jackson PK, Kirschner MW. Mitosis in transition. Cell Elsevier. 1994; 79:563-71.

38. Green DR, Chipuk JE. Apoptosis: Stabbed in the BAX. Nature. Nat Publ Group; 2008:455:1047.

39. Chipuk JE, Green DR. How do BCL-2 proteins induce mitochondrial outer membrane permeabilization? Trends cell biol. Elsevier. 2008;18:157-64.

40. Jin C-Y, Park C, Cheong J, Choi BT, Lee TH, Lee J-D, et al. Genistein sensitizes TRAlL-resistant human gastric adenocarcinoma AGS cells through activation of caspase-3. Cancer Lett. Elsevier. 2007;257:56-64.

41. Herceg Z, Wang Z-Q. Failure of poly (ADP-ribose) polymerase cleavage by caspases leads to induction of necrosis and enhanced apoptosis. Mol Cell Biol Am Soc Microbiol. 1999;19:5124-33.

42. Hohenberger P, Gretschel S. Gastic cancer. Lancet Elsevier. 2003;362:305-15.

43. Guggenheim DE, Shah MA. Gastric cancer epidemiology and risk factors. J Surg Oncol Wiley Online Library. 2013;107:230-6.

44. Hua H, Li M, Luo T, Yin Y, Jiang Y. Matrix metalloproteinases in tumorigenesis: an evolving paradigm. Cell Mol Life Sci Springer. 2011;68:3853-68.

45. Noh S, Jung J-J, Jung M, Kim TS, Park CH, Lim SJ, et al. MMP-2 as a putative biomarker for carcinomatosis in gastric cancer. Hepatogastroenterology. 2011;58:2015-9.

46. Lim SC. Expression of matrix metalloproteinases and its inhibitor in gastric adenocarcinoma. Cancer Res Treat Korean Cancer Association. 2001;33:199-206.

\section{Publisher's Note}

Springer Nature remains neutral with regard to jurisdictional claims in published maps and institutional affiliations.

Ready to submit your research? Choose BMC and benefit from:

- fast, convenient online submission

- thorough peer review by experienced researchers in your field

- rapid publication on acceptance

- support for research data, including large and complex data types

- gold Open Access which fosters wider collaboration and increased citations

- maximum visibility for your research: over $100 \mathrm{M}$ website views per year

At $\mathrm{BMC}$, research is always in progress.

Learn more biomedcentral.com/submissions 